\title{
FORMATION MECHANISM OF THE SHELL BEACH IN THE EAST SEA OF BRAZIL - A CASE OF THE ITAPEMA FORMATION IN THE SANTOS BASIN
}

\author{
WAN, L. K. - WU, Y. P.* - Ji, Z. F. - WEN, Z. X. - WANG, Z. M. -LI, Z. -QIN, Y. Q. - BIAN, H. G. \\ Research Institute of Petroleum Exploration \& Development of CNPC, Beijing 100083, China \\ *Corresponding author: Wu Yiping \\ e-mail: wuyiping01@petrochina.com.cn
}

(Received 24 $4^{\text {th }}$ Aug 2018; accepted $11^{\text {th }}$ Oct 2018)

\begin{abstract}
Based on the data of the seismic, drilling, cores, logging curves, this paper analyses the seismic reflection structure, drilling lithological, core deposit structure, core and thin section diagenetic porosity and permeability, puts forward the change Changes and cycle characteristics graded phenomenon of sediment grain size of Itapema shell beach in the Santos basin, reveals its formation mechanisms. Results show that the lithology of the Itapema is dominated by coquina, muddy coquina and argillaceous coquina. Bioclastic granule with calcium and bone shell becomes the material base of the shell limestone. Paleogeomorphology controls the shell beach's areal distribution, while lake level changes effect the spatial shifting and evolution law of shell beach. The shell beach could be divided into three sedimentary microfacies: main beach, beach wing, and slope of front-beach. Their distribution depends on the ancient landforms. The main beaches are located on the underwater paleo-uplift and consist of bivalve shell limestones with the developed holes and hillock seismic facies. Beach wings surround the uplifts, composed of muddy shell limestone. The slopes of front-beach are in the transitional area between the underwater paleo-uplift and the depocenter with shaly shell limestone and mudstone. The evolution and migration of the shell beach are influenced by the lake level changes. During HST the bivalve shell beach develops in the east uplifts; During TST the shell beaches shift to the periphery of east uplifts. During LST distribution of the shell beach gradually expands and small scale shell beaches begin to develop in the eastern depression. Therefore the eastern uplifts and the bulge in central and eastern depression can be regarded as favorable shell beach zones. The results of this study are helpful for offshore oil and gas exploration in this area.
\end{abstract}

Keywords: coquina, bioclast, ancient uplift, lake level changes, model

\section{Introduction}

As the main battlefield of exploration on both coasts of the Atlantic including the Santos Basin and Campos basin shifts to the deep-water field, values of the pre-salt lacustrine carbonate reservoir in exploration and scientific research become increasingly obvious. The huge lacustrine coquina in Eastern Sea of Brazil is a hot spot for global oil and gas exploration, which has great potential with low research level. Therefore the distribution of high-quality reservoirs is dependent upon the distribution of shell beaches. They are influenced by many factors, such as tectonic action, climate and hydrological conditions. Reservoir parameters including reservoir thickness and properties vary greatly in space and between boreholes. There are significant differences from other well-known biocarbonates (Wang et al., 2016). At the same time, the reservoirs are affected by the shielding effect of overlying salt rock, which results in poor seismic imaging quality and brings about great challenges in reservoir prediction and hydrocarbon exploration (Zhao et al., 2005). In the Eastern Sea of Brazil the formation mechanism of the shell limestone is not studied deeply, the main control 
factors are not clear (Liu et al., 2011; Zhu et al., 2017; Thompson et al., 2015; Wright, 2010, 2012; Gomes et al., 2009).

The Santos Basin is located offshore southeast Brazil, on the western coast of the South Atlantic (Fig. 1). The Cretaceous strata deposited in the basin can be divided into the Itapema and Barra Velha formations (Wang et al., 2016). The Lower Cretaceous Itapema formation consists of shell beaches deposited in the shallow to semi-deep lacustrine environment (Fig. 2).

As an important oil and gas reservoirs, shell limestone has been discovered to account for about 25\% of the reserves in East Sea of Brazil. It is of great significance for exploration, such as Libra and Lula oil fields. However, compared to marine carbonate rocks, shell limestone has small sedimentary scope and strong heterogeneity (Guo, 2011), and the degree and depth of research are far behind marine carbonate rocks. The paper takes shell beaches of Santos Basin as an example and analyzes petrological features, then puts forward control factors of the shell beaches and builds up the sedimentary model, which may provide geological basis for oil and gas exploration of the Itapema Formation in the Santos Basin.

\section{Materials and methods}

Because the lactustrine carbonate rocks formed in the more restrictive environment than those in the Marine environment, the formation mechanisms of shell beach are so complex that multiple data and methods are needed to reveal its control factors (Guo, 2011). Through analysis of paleotectonics and palaeoclimate, the sedimentary model was established by using core thin sections and seismic data and longing curve.

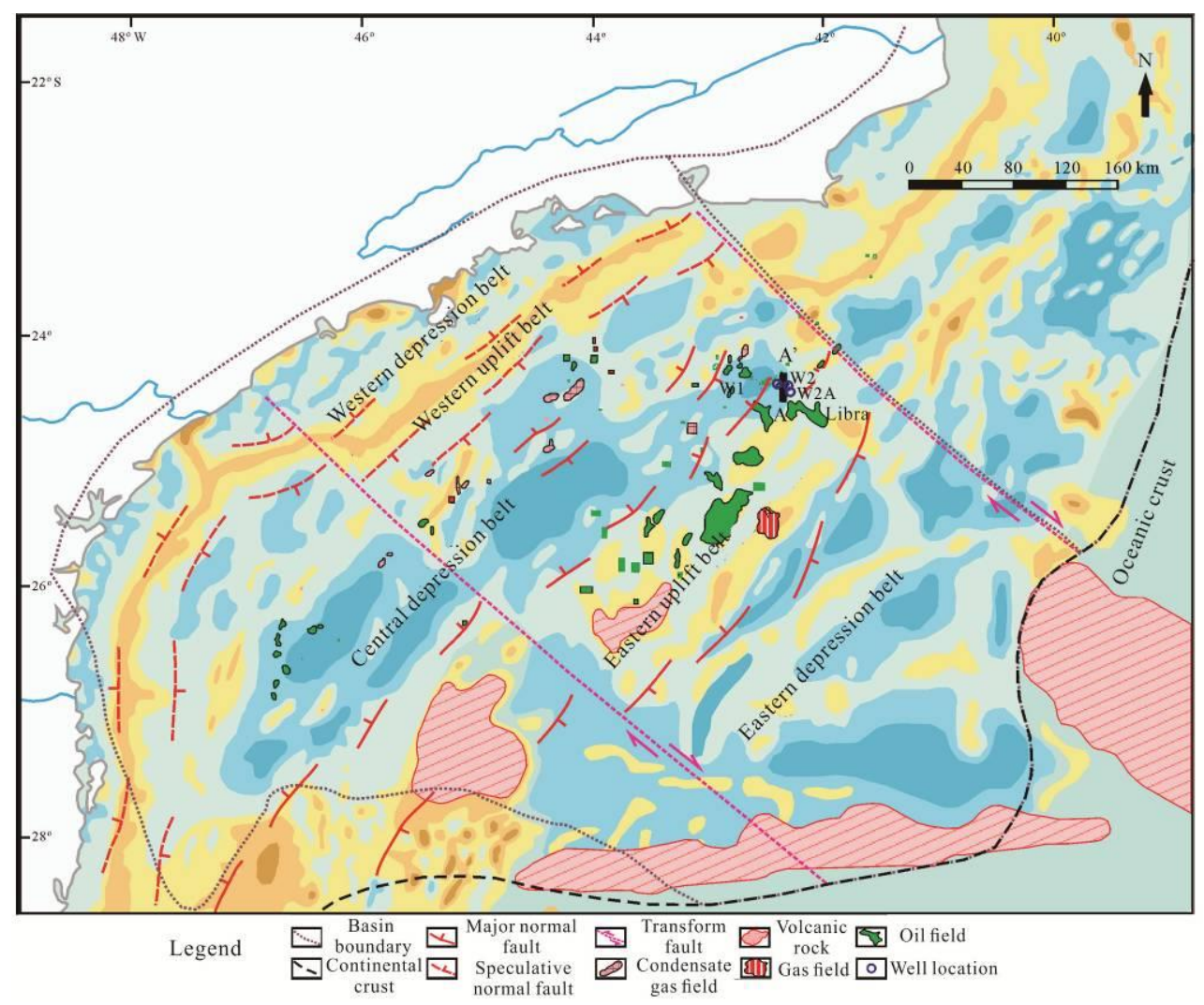

Figure 1. The tectonic setting of Santos Basin 


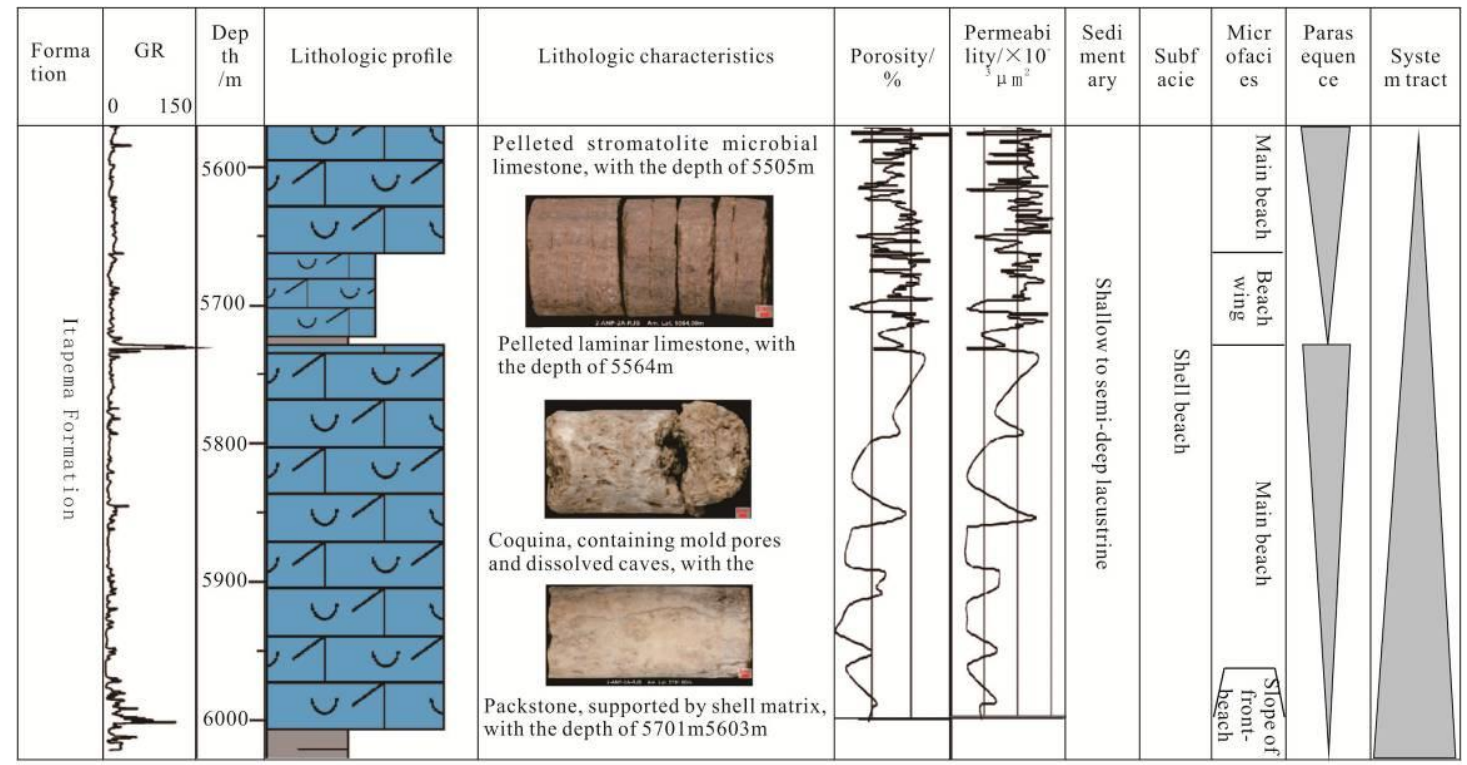

Figure 2. The sedimentary facies of Well W2

\section{Core and microscopic thin section}

Shell limestone, also known as Coguina (Zhu et al., 2017), is a tight sedimentary and composed of organic shell and bivalve fossils. The pre-salt coquina on both coasts of the Atlantic refers specifically to the lithologic complex comprised predominately by rigid bivalve shells, secondly by ostracoda and gastropods, and some other carbonate and siliciclastic compositions (Wright, 2012). Core and microscopic thin section observations indicate there are distinct differences in the upper and lower sections of the Itapema and the lithology is divided into coquina, muddy coquina and argillaceous coquina (Fig. 3).

\section{Coquina}

Coquina is located in the upper section. Typical coquinas include crystalline limestone, sparry coquina and micritic coquina (Fig. 3a), which are predominately grey brown-colored, moderate- to thick-bedded, blocky, and occasionally laminated. Their thickness is $13-30 \mathrm{~m}$, with larger wave cross-bedding and abundant mold pores and dissolved pores, and contain highly fragmented shells (Hou et al., 2017). The rock is characterized by the strong recrystallization of calcit and is composed of xenomorphic fine crystal-medium crystal calcite from $0.1 \sim 0.5 \mathrm{~mm}$. Coquina consists mainly of biogenic carbonate rock supported by $30 \%$ to $90 \%$ bioclasts, which contain lamellibranch and small amounts of ostracoda and gastropods. The shell bodies are partially broken in a long, flat and messy arrangement. The shell length is much less than $5 \mathrm{~mm}$, and the content varied from 70\% 90\%. In the upper sedimentary sequence, the content of the shell gradually increases, and the calcite grains gradually get larger. Coquina is one of the most favorable reservoirs in the basin.

\section{Muddy coquina}

Muddy coquina develops in the middle section of the cycle with small amounts of mold pores and dissolved pores, can be further divided into muddy sparry coquina and 
muddy micritic coquina (Fig. 3b), which present mainly grey- to dark grey-colored and moderate- to thin-bedded (Jian et al., 2008). The space between shells is filled with calcite and small amounts of mud (10\% to $25 \%)$. The cementation of the granule is about $35 \%$. The granule is dominated by double shell clastics with poor separation and distributes with weak orient. Granule content comes up 40 50\%. The shell fragment is different extremely with $\min 0.02 \mathrm{~mm}$ and $\max 3 \mathrm{~mm}$. In general muddy coquina has medium quality of the reservoir.
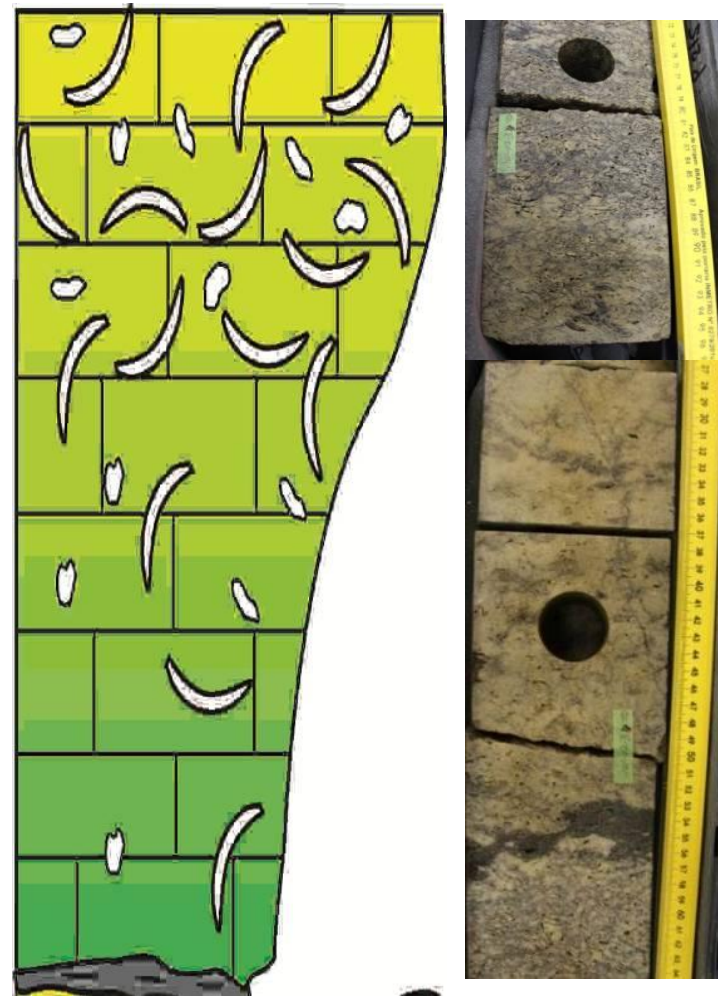
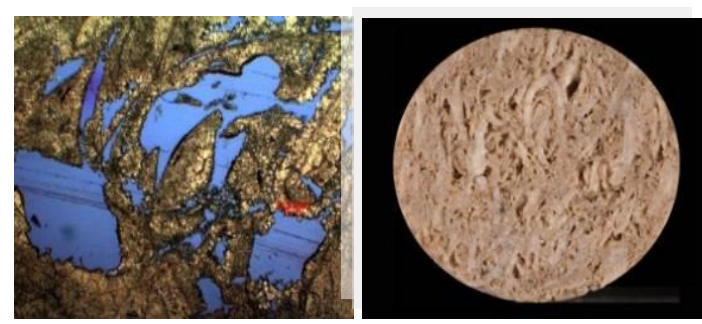

a. Coquina on the top of the cycle, $5335.87 \mathrm{~m}$, with abundant mold pores and dissolved pores

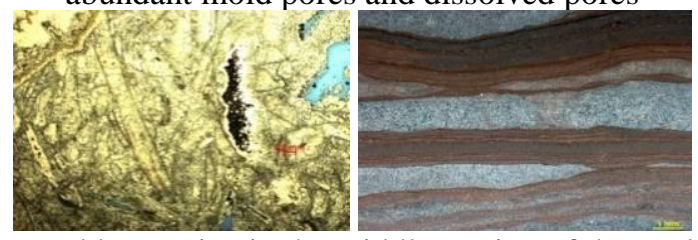

b. Muddy coquina in the middle section of the cycle, $5336.40 \mathrm{~m}$, with small amounts of mold pores and dissolved pores.

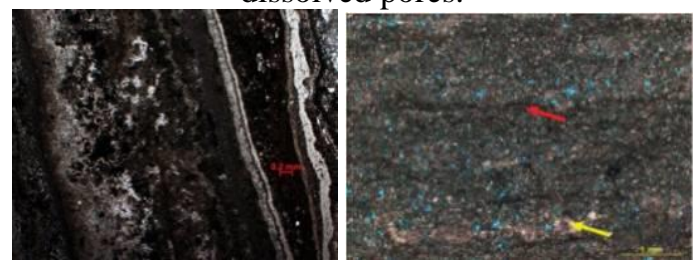

c. Argillaceous coquina in the lower section of the cycle, $5336.75 \mathrm{~m}$, tight

Figure 3. Dominate facies of coquinas of Itapema formation, Santos basin

\section{Argillaceous coquina}

Argillaceous coquina located in the lower section of the cycle (Fig. 3c), appears dark grey- to grey black-colored, with highly fragmented and directionally arranged shells. Granules are mainly bivalve clastic with disorder arrangement and poor separation, theri size $0.2 \sim 2 \mathrm{~mm}$, content around 50\%. Reservoir space is filled predominately with muds (25-45\%), bioclasts are dominated by lamellibranch and contain small amounts of ostracoda, and shells are predominately calcitic and partially aragonitic. There is a small amount of gray-black dung pellets locally with content of less than 5\%. Because of tight reservoir they can be defined as poor quality.

\section{Seismic reflection and logging curves}

Based on coquina's petrological characteristics, in combination with well logs and seismic facies analysis, the Lower Cretaceous Itapema Formation shell beaches could be divided into 3 microfacies: i.e., main beach, beach wing and slope of front-beach 
(Fig. 2). Coquina reservoirs in the study area are within the sedimentary facies belt having unique and district seismic reflection features (Fig. 4).

\section{Main beach}

The main beach is located in the upper end of the gentle-slope of the shallow lacustrine subfacies, and deemed to be high-energy beach sediments deposited in the freshwater lake basin. The lithology is dominated by coquina, which has the singlelayer thickness of $5 \mathrm{~m}$ or more (Fig. 2) and contains highly fragmented and densely stacked shells. This type of rock is blocky and relatively pure (Zhao, 2005). Microscopically, the bioclastic shells are generally crystallized and granulated, with no primary structure retained. This indicates that the water-body energy stayed high during the deposition of the main beach, so that shells were entirely broken (Wright, 2012). The main beach is characterized by strong-middle amplitude at peak and high continuity and intermittent clutter on seismic section (Fig. 4), and box-shaped on well log, with low-GR and High-Rt (Fig. 5). In LST (Lowstand System Tract), lowstand delta covers the western uplift belt in the proximity of the high-bulge, bioclastic slump fan was formed on the steep-slope to the lake-side of the margin of the uplift belt, and oolitic beach is present onto the inner gentle-slope at the margin of the uplift belt (Well W3).

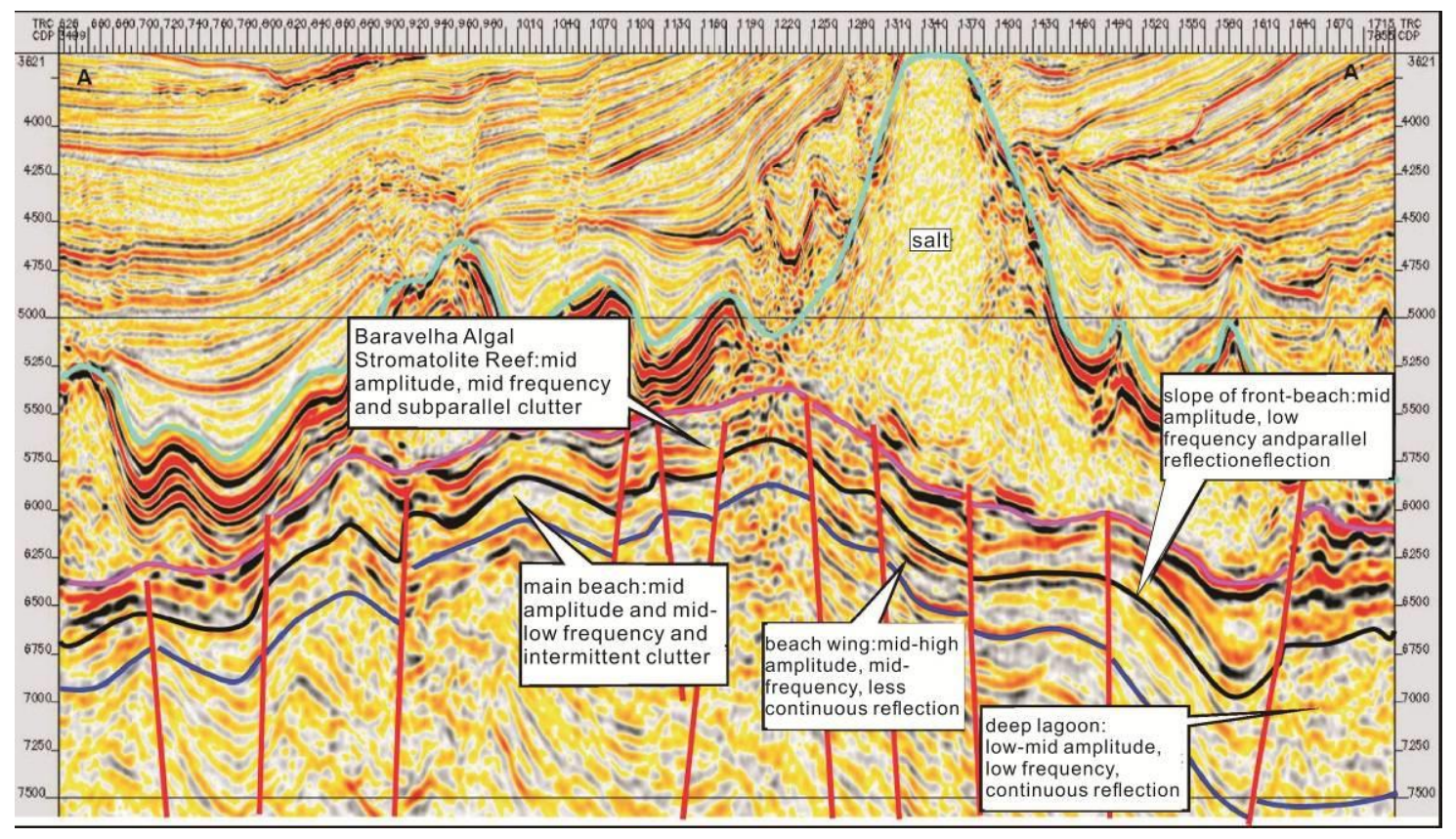

Figure 4. The seismic facies of Itapema formation in the Lower Cretaceous, Santos Basin

\section{Beach wing}

The beach wing is present in the periphery of the main beach, and varies in lithology across structural parts. Located to the leeside, the lithology of the back wing is dominated by limestone, indicating a relatively weak hydrodynamic force. The front wing, which is located to the windward side, and the side wings have the muddy coquina-dominated lithology, which has the single-layer thickness of 2 to $5 \mathrm{~m}$ (Fig. 2) and contains relatively intact but disorderly arranged shells, indicating a moderate hydrodynamic force (Zhao et al., 2005; Qin et al., 2014). The beach wing is 
characterized by middle-high amplitude at peak and middle frequency and less continuous reflection on seismic section (Fig. 4), and dentate-shaped on well log, with middle-GR and middle-Rt (Fig. 5). In TST (Transgressive System Tract), mollusk was prosperous, and bivalve-dominated organic reefs were developed at different periods (Guo, 2011). These reefs, as revealed by Well W4, have significant cumulative thickness, extend over a short distance in the lateral direction, and transition gradually into the organic reef back beach facies. Well W1 and W2 are drilled near the shoreland, where bioclastic sandy beach facies were formed by bioclasts carried by mixed storms and lake currents, under the influence of the injection of terrigenous clasts and alteration by wave winnowing. When the maximum lake transgression occurs, the limestonebuilding organisms were inhibited and lacustrine mudstone became dominant.

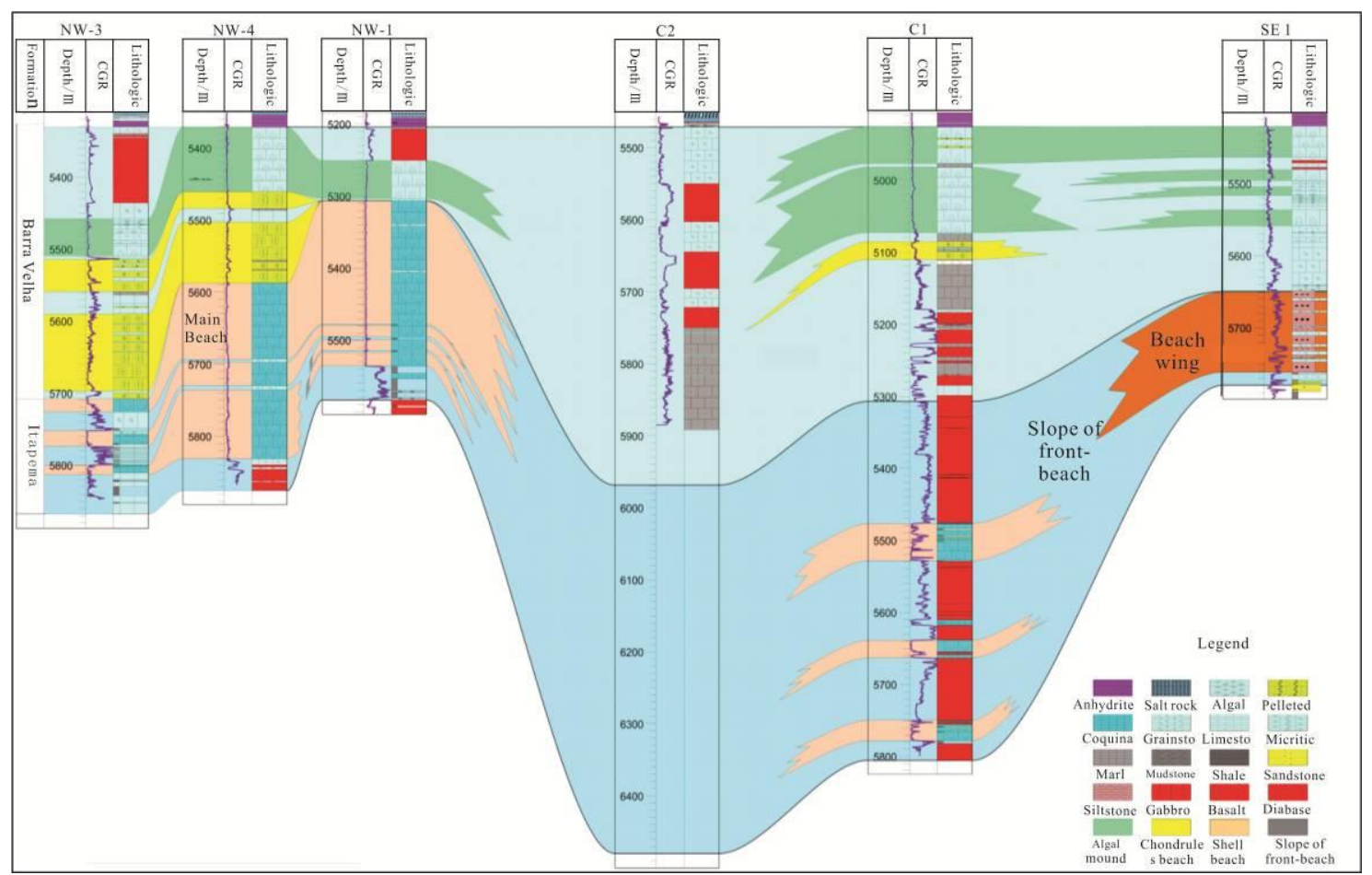

Figure 5. Section across Well NW3, NW4, NW1, C2, C1 and SE1 of Libra block in the Santos Basin

\section{Slope of front-beach}

The slope of front-beach is located to the windward side, within the transition zone between the shell beach and the lake basin center. The lithology is dominated by argillaceous coquina, which has the single-layer thickness of $2 \mathrm{~m}$ or less and is usually interbedded with dark mudstone. The main beach shell beds are fragmented by wave and then transported by lake wave to the slope of front beach and deposited to form argillaceous coquina, which is not the product of in-situ sedimentation and shares similar sedimentary mechanism with clastic rocks (Liu et al., 2011). Thus, argillaceous coquina contains highly fragmented and directional arranged shell beds (Guo, 2011). The slope of front-beach is characterized by middle amplitude at peak and low frequency and parallel reflection and moderate-strong continuity on seismic section (Fig. 4), and box-shaped and tooth-like on well logs, with low-GR and High-Rt (Fig. 5). 
As water level in HST (Highstand System Tract) began to drop gradually, limestonebuilding organisms (e.g., bivalve) were prosperous once again, the proportion of reefbeach facies bioclastic limestone tended to increase, and the water depth of facies belts generally decreases towards the shoreland.

\section{Results}

Study suggests that, the distribution and evolution of the Lower Cretaceous Itapema Formation shell beaches in the Santos Basin are controlled by Calcareous bioclast and paleo-geomorphology and lake level change. Particularly, Calcareous bioclast and paleo-geomorphology controls the shell beach's areal distribution, while sea level change control the spatial shifting and evolution law of shell beach (Liu et al., 2011; Liu and Lv, 2014).

\section{Calcareous bioclast}

Shell limestone in study profile is mainly composed of the bivalve shell and rare gastropods and mesomorphic shell, they accidentally contain chara, fish and other biological particles, so bioclastic granule with calcium and bone shell becomes the material base of the shell limestone (Fig. 3).

Bivalve shells are main granules of coquina, shell bodies are broken into clastic and are recrystallized, the large wave cross-bedding indicates that the rocks between granules can be sparry cementation. Penecontemporaneous karst reflects the rocks have been exposed soon after the sedimentary (Wright, 2012; Guo, 2011; Hou et al., 2017; Jian et al., 2008). So shell limestone formed in the high energy region between the minimum wave base on the sunny day and the lake level, related to the strong wave transformation and elutriation and cropped up above the lacustrine, shall be deposited in the uplift areas of the shell beach in the shore - shallow lacustrine.

Granules of muddy coquina are given priority to bivalve debris, mainly carbonate sediments with semi-solid or consolidation while the deposition has not been last so long. Then they suffered from waves, currents and storm flow, such as crushing, transportation, abrasion, redeposition. It reflects the strong hydrodynamic conditions. Therefore, it is speculated that muddy coquina may be formed on the medium-high energy environment between the minimum wave base and the maximum wave base on the sunny day, proved to be an integral part of the shell beach.

Granules of argillaceous coquinas derive mainly from bivalve debris with low recrystallization, interstitial fillings contain mainly micritic calcite and clay minerals (Mann and Rigg, 2012), which indicates that the sedimentary water body is deeper, and it has been affected by the weak wave action and incomplete elutriation. On the basis of that Granules of coquinas are transported to the shallow lakes on the low-energy environment and unload quickly in clay, plaster, deposit on the edge of the shell beach. So they may appear between the minimum wave base and the $\mathrm{v}$ wave base on the sunny day due to seasonal lake level changes.

\section{Paleo-geomorphology}

The tectonic framework of the Santos Basin consists of three depressions and two uplifts. In the basin lacustrine carbonate rocks are generally distributed over the underwater paleo-uplifts (Altenhofen, 2013), which are related to the shell bench. 
The main beach is the uplift part of the shell beach with the strongest wave energy and the thickest shell, where the pure shell limestone develops, and is represented by well NW4, NW1 and C1. Beach slope is the edge of the shell beach, far from the center of shell deposition, with weak wave energy and thinner shell, turns into development zone of argillaceous coquinas, represented by well $\mathrm{C} 1$ and C2. Sand content is higher close to the edge of the lakeside than that close to half deep lake (Brun and Fort, 2011). The beach wing is the slope part of transiting from the main beach to the beach edge with the strong wave energy, is the mixed development zone of the pure shell and the muddy shell, and represented by well SE-1 (Fig. 5).

Due to the screening effect of the western uplift belt, the majority of the terrigenous clasts transported by the rivers flowing into the lake to the west were deposited in the western depression belt. The increase in water depth of the central depression belt allowed for further purification of lake water. As a result of this, the eastern uplift belt became a favorable site for deposition of lacustrine carbonate rock (Fig. 6), because it was under a shallow lacustrine environment with moderate water depth and relatively strong wave action, which favors growth of lamellibranch. Thus, the shell beaches, particularly the main beach microfacies, are well developed (Fig. 5). In the periphery of the underwater low-bulge, beach wing sediments were formed resulted from the decrease in water energy (Brun and Fort, 2011; Jia et al., 2008). Sedimentation products are dominated by muddy coquina, which contains less shell fragments and interstitial materials. In the transition zone between the underwater low-bulge and the center of the lake basin, which is the transition zone between the shallow lacustrine and the semideep lacustrine environments with significant water depth and weakest hydrodynamic force, however, shelly organisms are less likely to grow and it is mainly the slope of front-wing microfacies formed. In the relatively low-lying paleo-gully present between the underwater low-bulges, which has relatively deeper water depth and weaker hydrodynamic force than the low-bulge zone, sediments deposited are similar to the beach wing or slope of front-wing microfacies. In addition, the development of shell beaches is related closely to the second-order paleo-geomorphological highs. All of these evidences reveal that, paleo-geomorphology has significant control on distribution of shell beaches.

\section{Lake level change}

The in-depth study of drilling and outcrop data indicates that, the Itapema formation can be roughly considered as a complete lacustrine transgressive cycle (Jia et al., 2008; Zhao et al., 2005), with shell beach sediments formed. Studies show that Itapema Formation mainly develops shell beach deposition in the early and date phases. The scale and evolution of shell beaches are controlled primarily by lake level change (Wang et al., 2016; Hou et al., 2017). Distribution of shell beach is chartered by migrating from northeast to southwest (Fig. 6).

During the initial period of lake level rise, the sedimentary environment transitions gradually from the coastal lake to the shallow lake, shell beaches began to form in the low-uplift zone in the center of the lake basin, but with relatively small scale and thickness, and in the uplift zone in the periphery of the lake basin shell beaches were absent due to the frequent exposure to the water surface. Along the shallow lake facies, there are five shell benches, including 45-215, 80-160, 25-145, etc., each of which transformed from the the beach core to the beach slope and to the beach edge, with three zonal pattern spreading (Fig. 6). 


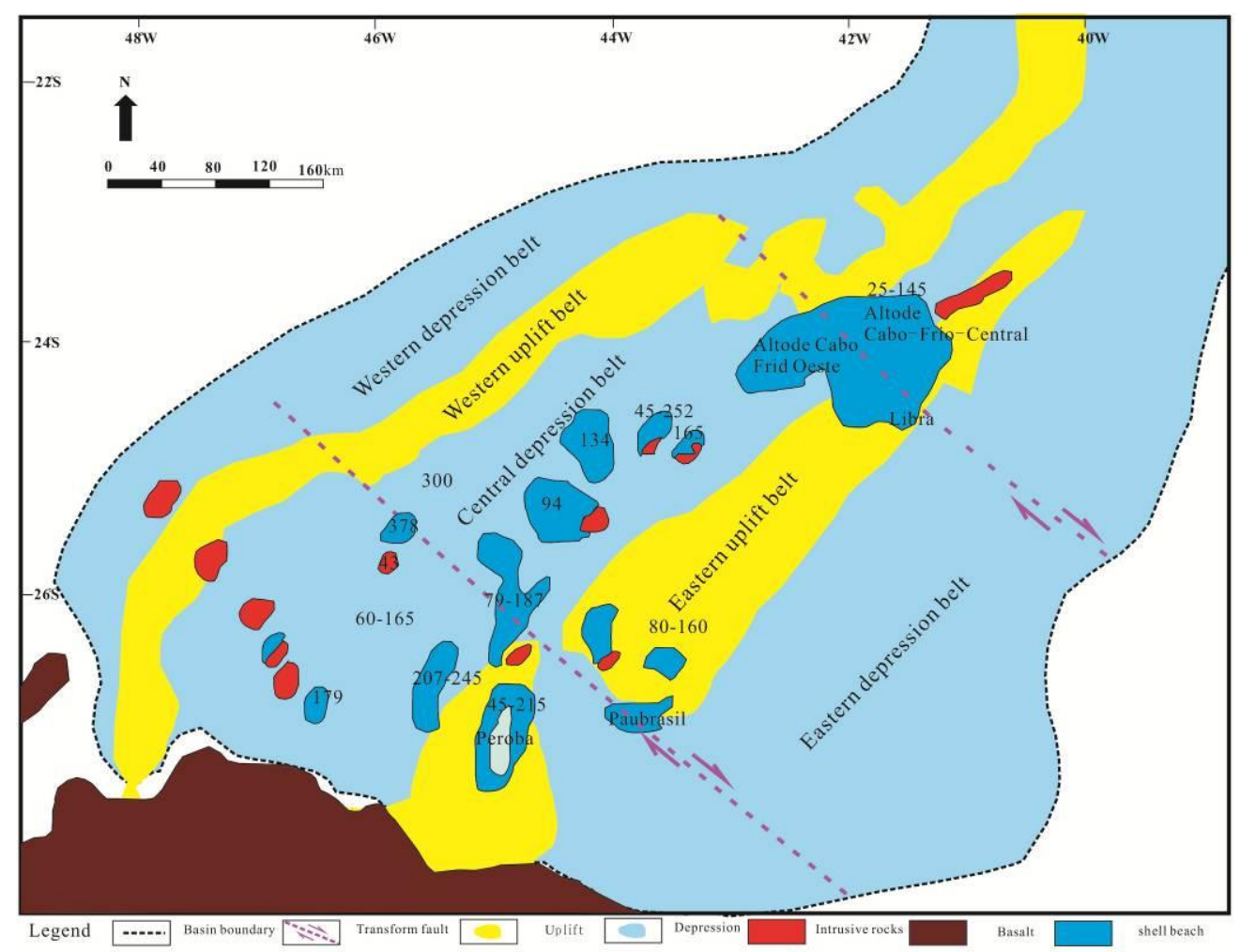

Figure 6. Distribution of shell beach of Itapema formation, Santos basin

During the middle-late period of lake level rise and initial period of lake level fall, lake level rose continually to its maxima, the moderate water depth and availability of abundant lamellibranch permit the shell beaches to form in the underwater uplift zone in the periphery of the lake basin. These shell beaches are commonly thick-bedded and extend over a broad area. In the low-uplift zone in the center of the lake basin (Tellus, 2012), however, the shell beaches are either decreased in scale or vanish due to the increase in water depth.

During the middle-late Itapama period of lake level fall, sedimentary environment transitioned gradually from the shallow lake to the coastal lake, and the influence of outer provenances became increasingly strong. As a result, shell beaches atrophied gradually, were present only in the low-uplift zone in the center of the lake basin and absent in the uplift zone in the periphery of the lake basin (Wang et al., 1981). Along the shallow sea facies some smaller 9 shell beaches developed, including 134-934 and 79-187 (Fig. 6).

The three periods of zonal pattern distribution control developing scope of three types of shell limestone, which has a certain difference in the planar.

\section{Discussion}

Based on the study of the seismic reflection structure, drilling lithological, core deposit structure, core and thin section, in combination with the change Changes and cycle characteristics graded phenomenon of sediment grain size of Itapema shell beach in the Santos basin (Garcia et al., 2012), we build the sedimentary model of the Lower Cretaceous Itapema Formation (Fig. 7). 


\section{Sedimentary model}

In the Santos Basin, the land side of the western uplift zone blocked the majority of terrigenous clasts to the west, and the lake side permits the formation of lake basin marginal platform, due to the influence of reverse synsedimentary faults (Garcia et al., 2012; Modica and Brush, 2004). The fault slope-break belt at the margin of the western high-bulge allows for formation of a coastal lacustrine sedimentary environment, which, with shallow but turbulent water body and strong winnowing effect, favors the sorting of clastic rocks and the development of beach limestones. Accordingly, lake margin, bioclastic sandy beach and bioclastic calcareous beach facies belts were deposited in areas extending from the shoreland to the lake. Lagoon facies belt was formed in the intraplatform low-lying areas on the slope. The fault slope-break belts at the margin of the depression formed a positive high structural setting at the platform margin, where the high-energy and clean shallow lacustrine environment allows for accumulation and prosperity of bivalve and homonemeae organisms. Accordingly, the organic reef facies limestone with a wave-resistance framework was formed, and these reefs are connected and merged to form the linear rim of the platform. In back-reef areas, water body remained turbulent, and bioclasts transported by lake wave altering storms enabled formation of back-organic reef beach and oolitic beach facies belts (Brun and Fort, 2011). In areas outside the fault slope-break belt at the margin of the depression, the slope gradient rose rapidly, and clasts formed by upstream weathering and erosion or storming would accumulate to form bioclastic slump fan.

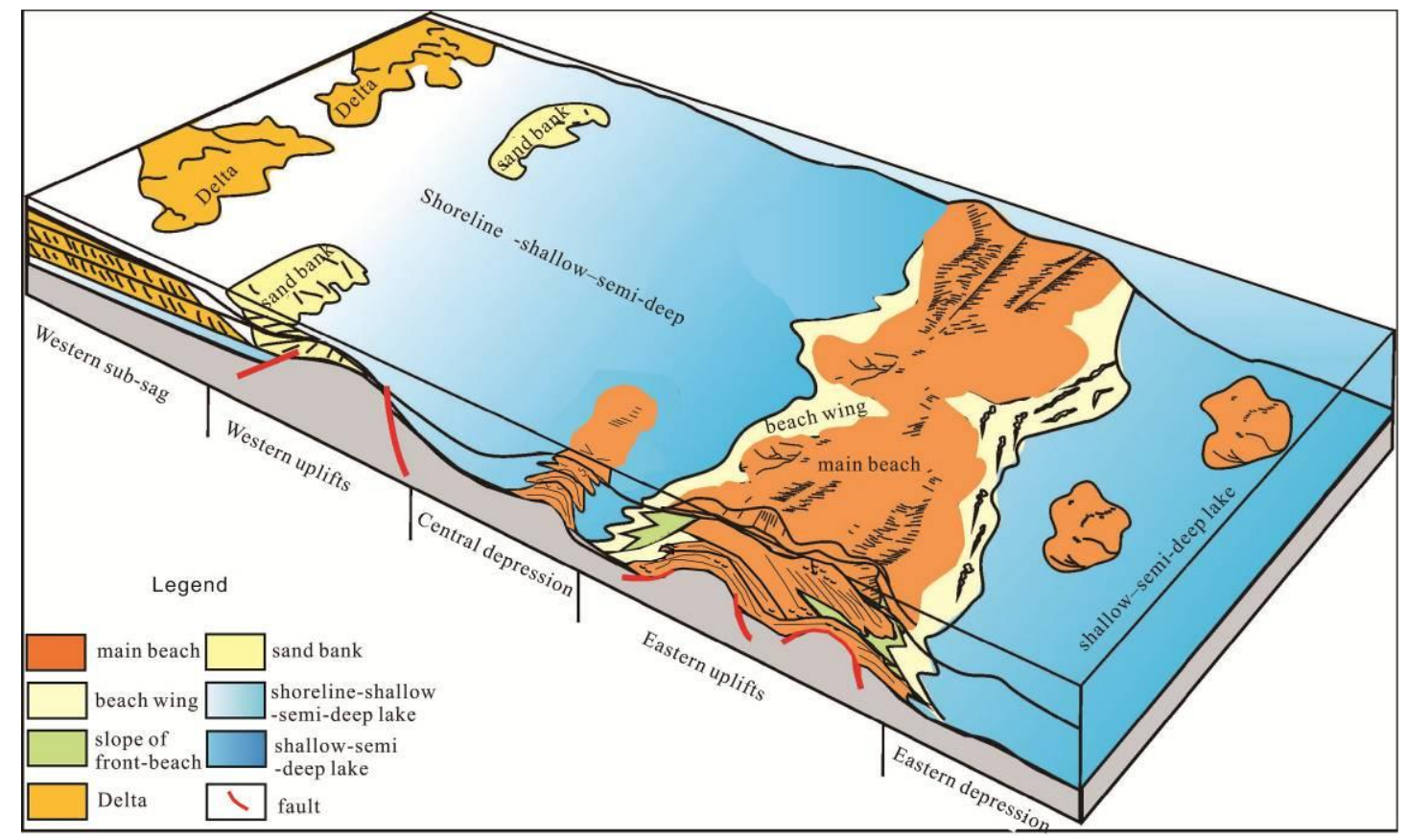

Figure 7. Depositional model diagram of the Itapema Group, Santos basin

\section{Favorable reservoirs}

Itapema Formation recorded the maximum lacustrine transgression occurred during the Cretaceous. The main part of the basin was covered by the still-water lake basin sediments and relatively less affected by outer provenances, with exceptional 
development of (fan) delta and flooding plain sediments in the periphery of the basin resulted from outer provenances (Xiong et al., 2013). This laid a solid foundation for large-area distribution of shell beaches. Areally, the shell beaches are distributed mainly in the underwater low-bulge belt, surrounding the depocenter. Vertically, the shifting and evolution of shell beaches are controlled primarily by the lake level change: shell beaches shifted gradually towards the shoreland during the lake level rise and towards the lake basin during the lake level fall. Building the sedimentary model has great significance to predicting the distribution of "sweet spot" reservoirs in the Itapema Formation and searching for favorable supplementary blocks (Dorobek, 2008).

\section{Conclusions}

(1) The Cretaceous Itapema Coquina in the Santos Basin deposited in shallow to semi-deep lacustrine and is dominated by coquina, muddy coquina and argillaceous coquina. Sedimentary facies of shell beaches are defined as main beach, beach wing and slope of front-beach.

(2) Distribution and evolution of the Lower Cretaceous Itapema shell beaches are controlled by Calcareous bioclast and paleo-geomorphology and lake level change. Particularly, Calcareous bioclast and paleo-geomorphology controls the shell beach's areal distribution, while sea level change control the spatial shifting and evolution law of shell beach.

(3) The vertical evolution of shell beaches is controlled primarily by lake level change. The eastern uplifts and the bulge in central and eastern depression can be regarded as favorable shell beach zones.

Acknowledgements. This project is supported by the National Science and Technology Major Project of China (Grant No. 2016ZX05029).

\section{REFERENCES}

[1] Altenhofen, S. D. (2013): Caracterizao petrografica de depositions carbonáticos lacustres do Grupo Lagoa Feia, Bacia de Campos, Brasil. Monografia (Trabalho de Conclus o de Curso). - Universidade Federal do Rio Grande do Sul. orto Alegre, Brasil.

[2] Brun, J., Fort, X. (2011): Salt tectonics at passive margins: geology versus models. Marine and Petroleum Geology 28(6): 1123-1145.

[3] Dorobek, S. L. (2008): Tectonic and Depositional Controls on Syn-Rift Carbonate Platform Sedimentation. - In: Lukasik T. J., Simoj, A. (eds.) Controls on Carbonate Platform and Reef Development. SEPM Special Publication 89, Tulsa, Oklahoma, USA, pp. 57-81.

[4] Garcia, S. F., Letouzey, J., Rudkiewicz, J. et al. (2012): Structural modeling based on sequential restoration of gravitational salt deformation in the Santos Basin (Brazil). Marine and Petroleum Geology 35(1): 337-353.

[5] Gomes, P. O., Kilsdonk, B., Minken, J. et al. (2009): The outer high of the Santos Basin, southern So Paulo Plateau, Brazil: pre-salt exploration outbreak, paleogeographic setting, and evolution of the syn-rift structures. - AAPG Search and Discovery, Denver, USA.

[6] Guo, F. (2011): Carbonate Sedimentology. - Petroleum Industry Press, Beijing, pp. 224225.

[7] Hou, G., Ni, C., Chen, W. et al. (2017): Sedimentary characteristics and factors controlling the Shell Beach in the Da'anzhai member of the Central Sichuan Basin. - 
Journal of Southwest Petroleum University (Science \& Technology Edition) 39(1): 2534.

[8] Jia, Z., Hong, T., Wang, W. (2008): The building process and influential factors of the stromatolite reefs in the neoproterozoic Jiuliqiao Formation in Huainan region, Anhui. Acta Palaeotologica Sinica 47(1): 47-57.

[9] Jian, H., Yuan, X. et al. (2008): Analysis on sequence stratigraphy of lacustrine carbonate in the first member of Shahejie Formation in huimin Sag. - Acta Petrolei Sinica 29(2): 213-218.

[10] Liu, S., Hu, X., Li, J. (2011): Great discovery and its significance fro exploration in subsalt reservoir in Santos Basin, Brazil. - Overseas Exploration 16(4): 74-81.

[11] Liu, Z., Lv, M. (2014): Analysis of pre-salt geological characteristics of deepwater basins in South Atlantic Ocean. - China Petroleum Exploration 19(6): 63-73.

[12] Mann, A., Rigg, J. (2012): New geological insights into the Santos Basin. - Geo ExPro 9(1): 36-39.

[13] Modica, C. J., Brush, E. R. (2004): Postrift sequence stratigraphy, paleogeography, and fill history of the deep — water Santos Basin, offshore Southeast Brazil. - AAPG Bulletin 88(7): 923-945.

[14] Qin, Y., Wen, Z., Wang, Z. et al. (2014): Sedimentary characteristics, model and hydrocarbon accumulation of deep water pre-salt carbonate rocks in South Atlantic. Earth Science Frontiers 21(1): 21-31.

[15] Tellus (2013): Tellus data B/OL. - http://www.fugro-robertson.com/products/tellusFRL (2012-12-30).

[16] Thompson, D. L., Stilwell, J. D., Hall, M. (2015): Lacustrine carbonate reservoirs from Early Cretaceous rift lakes of Western Gondwana: pre-salt coquinas of Brazil and West Africa. - Gondwana Research 28(1): 26-51.

[17] Wang, J. et al. (1981): Diagenesis and digenetic trap of Daanzhai limestone. Geochimica 30: 232-241.

[18] Wang, Y., Wang, X., Liao, J. et al. (2016): Cretaceous lacustrine algal stromatolite reef characteristics and controlling factors, Santos Basin, Brazil. - Acta Sedimentologica Sinica 34(5): 819-829.

[19] Wright, V. P. (2010): Reservoir architectures in non-marine carbonates (abs.). - AAPG Annual Convention and Exhibition, Houston, Texas, USA, pp. 10-13.

[20] Wright, V. P. (2012): Lacustrine Carbonates in Rift Settings: The Interaction of Volcanic and Microbial Processes on Carbonate Deposition. Advances in Carbonate Exploration and Reservoir Analysis. - Geological Society Special Publication 370, London, pp. 3947.

[21] Xiong, L., Li, J., Wu, C. et al. (2013): Tectonic evolution and hydrocarbon accumulation in the Solimoes Basin, Brazil. - Oil \& Gas Geology 34(3): 363-369.

[22] Zhao, J., Xia, B., Ji, Y. et al. (2005): Analysis of the high resolution sequence of lacustrine carbonate. - Acta Sedimentologica Sinica 23(4): 646-656.

[23] Zhao, J., Xia, B., Ji, Y. et al. (2005): Analysis of the high resolution sequence of lacuatrine carbonate. - Acta Sedimentologica Sinica 23(4): 646-656.

[24] Zhu, S., Wu, K., Lyu, M. et al. (2017): Characteristics and sedimentary model of lacustrine coquina in Campos Basin, Brazil. - China Offshore Oil and Gas 29(2): 36-45. 